\title{
Habitat heterogeneity as a key to high conservation value in forest-grassland mosaics
}

\begin{abstract}
Forest-grassland mosaics are widespread features at the interface between tree- and grassdominated ecosystems. However, the importance of habitat heterogeneity in these mosaics is not fully appreciated, and the contribution of individual woody and herbaceous habitats to the overall conservation value of the mosaic is unclear. We distinguished six main habitats in the forest-grassland mosaics of the Kiskunság Sand Ridge (Hungary) and compared the species composition, species richness, Shannon diversity, naturalness, selected structural features, environmental variables, and the number of protected, endemic, red-listed and specialist species of the plant communities. Each habitat had species that were absent or rare elsewhere. Grasslands had the highest conservation importance in most respects. North-facing forest edges had the highest species richness, while south-facing edges were primarily important for tree recruitment. Among the forest habitats, small forest patches were the most valuable, while large and medium forest patches had the lowest conservation importance. We showed that the current single-habitat focus of both research and conservation in the studied forestgrassland mosaics is not justified. Instead, an integrated view of the entire mosaic is necessary. Management practices and restoration projects should promote habitat heterogeneity, e.g., by assisting tree and shrub establishment and survival in grasslands. The legislative background should recognize the existence of fine-scale forest-grassland mosaics, which are neither grasslands nor forests, but a mixture.
\end{abstract}

Keywords: Complexity, Conservation management, Forest edge, Forest patches, Foreststeppe, Landscape heterogeneity

\section{Introduction}

The intensification of land-use practices and the resulting habitat homogenization pose major challenges for current conservation (Ernst et al., 2017; Foley et al., 2005; Rembold et al., 2017; Stoate et al., 2001). Likewise, land abandonment often leads to homogenization (Bergmeier et al., 2010; Plieninger et al., 2015; Ernst et al. 2017). Generally, heterogeneous areas are expected to contain more niches and, consequently, more species than homogeneous areas (Bazzaz, 1975; Chesson, 2000; Tilman, 1982). In fact, spatial heterogeneity seems necessary for the maintenance of biodiversity, ecosystem services, and endangered species (Armengot et al., 2012; Dorresteijn et al., 2015; Valkó et al., 2012). Thus, from a conservation perspective, the presence of various habitat patches in close proximity is considered beneficial (Jakobsson and Lindborg, 2015; Tölgyesi et al., 2017).

Habitat heterogeneity and its conservation implications are relatively well studied in agricultural and agroforestry landscapes (e.g., Bennett et al., 2006; Benton et al., 2003; Jakobsson and Lindborg, 2015; Lee and Martin, 2017; Manning et al., 2006; Moreno et al., 2017; Plieninger et al., 2015; Stoate et al., 2001; Tscharntke et al., 2005). Unfortunately, the importance of habitat heterogeneity for conservation has received less attention in natural mosaics at the interfaces of tree- and grass-dominated biomes (cf. Tews et al., 2004).

Forest-grassland mosaics typically consist of numerous types of forest and grassland patches of various sizes, as well as intervening edge communities, with strongly different physiognomies and environmental conditions (Breshears, 2006; Schultz, 2005). In such mosaics, appropriate conservation actions and adequate management strategies require an integrated view of the complex ecosystem (Luza et al., 2014). 
Forest-grassland mosaics represent high conservation significance (Erdős et al., 2018; Prevedello et al., 2018). However, in Eastern Europe, most of these mosaics have been transformed to croplands or non-native tree plantations, while the remaining fragments are threatened by different forms of homogenization (Wesche et al., 2016). In some regions, the spontaneous or human-induced spread of woody species may result in the disappearance of grassland habitats. At the same time, woody habitats are diminishing in other regions due to the combined effects of climate change, sinking groundwater level, and fire (Molnár, 1998; Wesche et al., 2016).

The conservation importance of habitat heterogeneity in the natural forest-grassland mosaics of Eastern Europe is, as yet, not fully appreciated. Ecological studies have typically focused on either the grassland or the forest component separately, disregarding the mosaic character (Erdős et al., 2015). The same bias exists in conservation practice. For example, restoration efforts usually aim to reconstruct only one of the components (e.g., Filatova and Zolotukhin, 2002; Halassy et al., 2016; Szitár et al., 2016; Török et al., 2014). Projects that intend to restore entire mosaic complexes (i.e., both woody and herbaceous components) are scarce (Török et al., 2017). While grazing and mowing are traditional and effective tools in both restoration and conservation management, changes in land-use in the form of either intensification (e.g., overgrazing, mechanized mowing) or abandonment may reduce heterogeneity and may thus have a detrimental effect on these complex systems (Bergmeier et al., 2010; Öllerer, 2014; Tölgyesi et al., 2017).

In this study, our aim was to explore the contribution of individual woody and herbaceous habitats to the overall conservation value of the entire mosaic. Our questions were the following: (1) If we aim to protect the entire species pool of the mosaic, is it sufficient to conserve one or a few keystone habitats, or is it necessary to conserve all of them? (2) What is the importance of individual habitats in terms of conservation-related characteristics (species richness, diversity, the number of species with special conservation relevance, naturalness, tree size-classes and recruitment, adventives)? (3) How does environmental heterogeneity support the observed vegetation pattern?

\section{Material and methods}

\subsection{Study area}

The study was conducted in the Kiskunság Sand Ridge, which is a lowland area between the Danube and Tisza rivers in Hungary. Three study sites were selected:

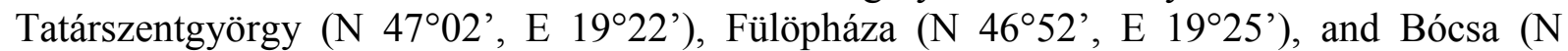
$46^{\circ} 41^{\prime}$, E $19^{\circ} 27^{\prime}$ ) (Fig. 1a). All three sites are part of the Natura 2000 network of protected areas, and the Fülöpháza and Bócsa sites belong to the Kiskunság National Park. The mean annual temperature is $10.3-10.5{ }^{\circ} \mathrm{C}$, and the mean annual precipitation is $520-550 \mathrm{~mm}$ (Tölgyesi et al., 2016). The study sites are characterized by stabilized calcareous sand dunes and interdune depressions that are covered by humus-poor sandy soils with low water retention capacities (Várallyay, 1993).

The vegetation is a mosaic of woody and herbaceous components (Fig. 1b). The open perennial sand grassland (Festucetum vaginatae, Natura 2000 category: 6260, *Pannonic sand steppes, a habitat of community importance in the European Union) is the most widespread natural herbaceous community of the study sites. The total cover of vascular plants usually varies between 40 and $70 \%$, and the rest of the area is covered by mosses, lichens, or bare sand. The dominant species are Festuca vaginata, Stipa borysthenica, and S. capillata, while Alkanna tinctoria, Dianthus serotinus, Euphorbia segueriana, Fumana procumbens, and Poa bulbosa are also common. 
Patches of the juniper-poplar forest (Junipero-Populetum albae, Natura 2000 category: 91N0, Pannonic inland sand dune thicket) are scattered in the grassland. The canopy layer has a cover of $40-60 \%$ and is co-dominated by $10-15 \mathrm{~m}$ tall Populus alba and $P$. $\times$ canescens individuals. The shrub layer cover varies between 5 and $80 \%$ with heights of $1-5 \mathrm{~m}$, and is composed of Berberis vulgaris, Crataegus monogyna, Juniperus communis, and Ligustrum vulgare. The most common species in the herb layer include Anthriscus cerefolium, Asparagus officinalis, Carex liparicarpos, Cynoglossum officinale, Poa angustifolia, and tree and shrub seedlings. Some xeric species, such as Eryngium campestre, Festuca rupicola, and Potentilla arenaria, are mainly found under canopy gaps. The sizes of the forest patches range from a few individual trees (approx. $50 \mathrm{~m}^{2}$ ) to a few hectares, although patches larger than 1 ha are rare.

The study sites were extensively grazed till the end of the 19th century. In the 20th century, the Fülöpháza and the Bócsa sites were used for military exercises, which stopped in 1974 (Biró et al., 2013; Kertész et al., 2017). Currently the level of anthropogenic disturbances is very low (strictly regulated tourism and research). There is strong evidence that the mosaic character is a result of climatic features and soil characteristics, and the grassland component persists even without grazing or other forms of disturbances (Bodrogközy, 1982; Erdös et al., 2015; Fekete, 1992). Both the position and the extent of the studied habitat patches are relatively stable at a decadal time-scale: grassland-to-forest or forest-to-grassland transitions are rare and occur very slowly (Erdös et al., 2015; Fekete, 1992).

\subsection{Sampling design}

Based on previous research (Erdős et al., 2015), six habitat types were distinguished in the present study: large forest patches $(>0.5 \mathrm{ha})$, medium forest patches (0.2-0.4 ha), small forest patches $(<0.1 \mathrm{ha})$, north-facing forest edges, south-facing forest edges, and grasslands. Patches were selected randomly for the study. Plots within the individual patches were placed so as to ensure representativeness and avoid degraded areas such as road or path margins and plantations. Edge plots were established in more or less straight peripheral zones of forest patches $>0.2$ ha outward from the outermost tree trunks but still under the canopy. We sampled a total of 90 permanent plots ( 3 sites $\times 6$ habitats $\times 5$ replicates). Plot size was $25 \mathrm{~m}^{2}$ $(2 \mathrm{~m} \times 12.5 \mathrm{~m}$ at edges, $5 \mathrm{~m} \times 5 \mathrm{~m}$ elsewhere). The sizes and shapes of the plots were determined according to the local circumstances: the size was small enough to sample even the smallest forest patches but large enough for a standard coenological relevé, whereas the elongated form of the edge plots ensured that they did not extend into the forest or grassland interiors.

Within each plot, the percent covers of all vascular plant species in all vegetation layers were visually estimated in April (spring aspect) and July (summer aspect) 2016. Visual estimations were done by the same person in all plots. Of the spring and summer cover values, for each species, the largest value was used for subsequent data analyses.

All individual trees were inventoried in the plots, and the diameter at breast height (DBH) was measured for trees taller than $1.3 \mathrm{~m}$.

As potential environmental drivers of vegetation in the different habitats, microclimate variables and soil moisture content were measured in 30 plots ( 6 habitats $\times 5$ replicates $)$ at the Fülöpháza site. Among the three study sites, Fülöpháza lies in the middle, in an almost equal distance from the other two sites. Air temperature $\left({ }^{\circ} \mathrm{C}\right)$ and relative air humidity $(\%)$ were measured synchronously for 24 hours at $25 \mathrm{~cm}$ above the ground surface in the centre of each plot using MCC USB-502 data loggers (Measurement Computing Corp). Microclimate loggers were housed in naturally ventilated radiation shields to avoid direct solar radiation, 
and the logging interval was set to $1 \mathrm{~min}$. Measurements occurred from 3 to 4 August under clear weather conditions. Soil moisture values were measured in the upper $20 \mathrm{~cm}$ layer on 26 July using a FieldScout TDR300 Soil Moisture Meter (Spectrum Technologies Inc). Five measurements were carried out for each plot, which were then averaged.

\subsection{Data analyses}

To assess the compositional relations of the six habitat types, we performed a nonmetric multidimensional scaling (NMDS) using Bray-Curtis distance on the square root transformed cover scores. We conducted the analysis with one to six axes and found that using three or more axes caused only slight and linear decreases of the stress factors compared with the two-dimensional solution, so we decided to use only two axes. The analysis was performed in $\mathrm{R}$ 3.4.3 ( $\mathrm{R}$ Core Team, 2017) using the 'metaMDS' function of the vegan package (Oksanen et al., 2016).

To identify the species that prefer one specific habitat type and are absent or rare in other habitats, we performed a diagnostic species analysis. The phi coefficient was applied as an indicator of the fidelity of a species to certain habitats (Chytrý et al., 2002). The phi coefficient varies between -1 and +1 ; higher values reflect higher diagnostic values. In this study, species with phi values $>0.200$ were considered. Significant $(P<0.01)$ diagnostic species were identified by applying Fisher's exact test. Analyses were performed with JUICE 7.0.45 (Tichý, 2002).

Species richness and Shannon diversity were computed for each plot, and the per plot number of species with special conservation relevance was also enumerated, which included all protected, endemic, red-listed and specialist species and was based on Borhidi (1995), Király (2007), and the Database of Hungarian Natural Values (www.termeszetvedelem.hu). As a numeric descriptor of habitat naturalness, we used the relative naturalness indicator values of Borhidi (1995), defined for the Hungarian flora. Naturalness indicator values are defined along an ordinal scale and reflect the observed tolerances of species against habitat degradation. Species that tend to be related to natural habitats have higher values, while species that are more frequent in degraded sites have lower values. Despite some criticism, bio-indication in general and naturalness indicators in particular have solid theoretical bases and obvious practical advantages (Diekmann, 2003). Earlier analyses have shown that mean naturalness values are able to indicate habitat naturalness/degradation (Erdős et al., 2017; Sengl et al., 2016, 2017). Here, we calculated the unweighted mean value for each plot, as it is more efficient in site indication than cover-weighted approaches (Tölgyesi et al., 2014).

The species richness, Shannon diversity, number of species with special conservation relevance, and naturalness values were analysed in the $\mathrm{R}$ environment with linear mixedeffects models. Site was included as the random factor and habitat was the fixed factor. We used a Poisson error term for the count data (species richness and the number of species with special conservation relevance) and assumed a Gaussian distribution for the continuous variables (Shannon diversity and mean naturalness value). We used the 'glmer' function of the lme4 package (Bates et al., 2015) for the former situation, and the 'lme' function of the nlme package (Pinheiro et al., 2016) for the latter one. The full models were tested for significance with analysis of variance, and if the model explained a significant proportion of the variability, we considered pairwise comparisons of the levels of the fixed factor. To account for multiple comparisons, we adjusted the resulting $P$ values with the false discovery rate (FDR) method.

The size-class distribution of the trees was studied using $5 \mathrm{~cm}$ diameter classes. The distributions were compared with the Kolmogorov-Smirnov test. Stand characteristics, such as the mean and maximum DBH and number of trees per ha, were calculated for both native 
and adventive species. The nativeness or adventiveness of the tree species was defined according to Király (2009), as shown in Table A1.

Using the collected microclimate data, we calculated the following variables: mean daily air temperature, mean daytime air temperature, mean nighttime air temperature, mean daily relative air humidity, mean daytime relative air humidity, and mean nighttime relative air humidity. Daytime was defined here as the interval from 7:01 a.m. to 7:00 p.m., while nighttime was the interval from 7:01 p.m. to 7:00 a.m.

To assess the relationships between environmental variables and vegetation pattern, we conducted a distance-based redundancy analysis (dbRDA) in the R environment using the 'capscale' function of the vegan package (Oksanen et al., 2016). The ordination was performed using Bray-Curtis distance on the square root transformed species cover scores. For a preliminary dbRDA model, we included seven environmental variables (all six microclimatic variables mentioned above, and soil moisture) and calculated the variance inflation factor (VIF) of each variable to check for multicollinearity. We then removed the variable with the highest VIF and recreated the model. We continued this step-by-step refinement until every VIF was less than five. Finally, we retained only daily mean temperature, nighttime mean temperature, daily mean relative humidity, and mean soil moisture. To find the best model using any of these four explanatory variables, we used the forward selection method ('ordistep' function). We tested the final dbRDA model and the effect of each explanatory variable for significance with analysis of variance using 1000 permutations each.

The plant species names follow Király (2009), while the plant community names are according to Borhidi et al. (2012).

\section{Results}

We found a total of 182 plant species in the 90 plots. The NMDS ordination indicated a well-defined gradient in the following sequence: large forest patches - medium forest patches - small forest patches and north-facing edges - south-facing edges - grasslands (Fig. 2). Most groups overlapped considerably (especially small forest patches and north-facing edges), but grasslands were distinct from the other habitats.

The significant $(P<0.01)$ diagnostic species of the six habitats are shown in Table A2. Large forest patches had seven diagnostic species, mostly native shrubs (e.g., Cornus sanguinea, Prunus spinosa). Two native shrubs (Crataegus monogyna, Berberis vulgaris) were identified as diagnostic species for medium forest patches. Seven species were significantly associated with small forest patches, most of which were herbs (e.g., Solanum dulcamara, Eryngium campestre). North-facing edges had ten diagnostic species (e.g., Carlina vulgaris, Polygala comosa). South-facing edges also had ten diagnostic species (e.g., Koeleria glauca, Poa bulbosa), of which they shared four species with the grassland habitat. Twenty species were associated with grasslands (e.g., Alkanna tinctoria, Fumana procumbens).

Habitat type had significant effects on species richness $\left(\chi^{2}=70.62, P<0.001\right)$, Shannon diversity $\left(\chi^{2}=12.31, P=0.031\right)$, the number of species with special conservation relevance $\left(\chi^{2}=129.16, P<0.001\right)$, and the mean naturalness value $\left(\chi^{2}=70.84, P<0.001\right)$. Considering the pairwise comparisons (Table A3), north-facing edges had the highest species richness followed by south-facing edges (Fig. 3a). Species richness was lowest in large and medium forest patches, while grasslands and small forest patches had intermediate species richness. There were no significant differences among the Shannon diversities of the different habitats, although north-facing edges and south-facing edges seemed to have somewhat 
higher Shannon diversity values than large, medium, and small forest patches (Fig. 3b). These differences were significant in only the uncorrected set of $P$ values. The number of species with special conservation relevance showed a gradually increasing trend from the large forest patches towards the grasslands (Fig. 3c). A similar pattern was detected for the mean naturalness values (Fig. 3d).

Recruitment of native trees (mainly Populus alba and $P . \times$ canescens, to a much lesser degree Quercus robur) seemed to occur in mainly the south-facing edges and to a lesser degree in the north-facing edges and grasslands (Fig. 4, Table 1). In contrast, the recruitment of adventive trees (e.g., Ailanthus altissima, Celtis occidentalis, Padus serotina, and Robinia pseudoacacia) was concentrated in the forest interiors of all patch sizes and north-facing edges, while it was rare in the south-facing edges and completely absent in grasslands. The numbers of larger native trees $(\mathrm{DBH}>5 \mathrm{~cm})$ were almost equal in large, medium, and small forest patches, while adventive trees with $\mathrm{DBH}>5 \mathrm{~cm}$ were present in only large forest patches. Large native trees $(\mathrm{DBH}>50 \mathrm{~cm})$ were present in mainly large and medium forest patches and to a lesser degree in small forest patches. Adventive tree species were not able to develop to large sizes in any of the studied habitats. According to the Kolmogorov-Smirnov tests (Table 2), the six habitats formed two groups: large, medium, and small forest patches were similar to one another, but differed significantly from the other three habitats (northfacing edges, south-facing edges, and grasslands).

The results of the environmental measurements are shown in Table A4. The best dbRDA model contained all four explanatory variables that were retained (daily mean temperature, nighttime mean temperature, daily mean relative humidity, and soil moisture), and it was significant $\left(R^{2}=0.276, F=3.76, P<0.001\right)$. Although three of the variables were retained during variable selection, they had nonsignificant effects (nighttime mean temperature: $F=1.28, P=0.214$, daily mean humidity: $F=0.98, P=0.394$, and soil moisture: $F=1.67, P=0.099$ ), and only daily mean temperature had a significant effect $(F=2.81, P=0.019)$. The dbRDA biplot (Fig. 5) indicated that woody (forest and edge) and non-woody (grassland) habitats were separated according to daily mean temperature, with higher values pointing towards the grassland. Interestingly, soil moisture, although having only a marginally significant effect, explained the distribution of the woody habitat types in the ordination space.

\section{Discussion}

\subsection{Compositional differences among habitats}

The composition of the studied habitats formed a gradient from large forest patches to grasslands. However, species turnover was not continuous, and two well-defined groups emerged. The first group contained the grassland habitat, which had the most distinct species composition and the highest number of diagnostic species, suggesting that the grassland species pool is poorly represented in other habitats. The second group consisted of all other (woody) habitats with partly overlapping species compositions and fewer diagnostic species. This most basic distinction (woody vs. herbaceous habitats) defines the minimum conservation requirement in the studied ecosystem: To represent a considerable proportion of the species pool of the landscape, it is necessary to preserve both the grassland and at least some of the woody habitats.

Given its relatively large variation, the woody habitat group may be further subdivided into edge-like habitats (small forest patches, north-facing edges, and south-facing edges) and forests with core areas (large forest patches and medium forest patches). To achieve a higher landscape-level diversity, it is recommended to conserve at least some edge-like habitats and 
some forest patches with core areas. However, our results emphasize that all six habitats have their typical species composition and species that are significantly concentrated within each of them. Thus, all habitats deserve special consideration in conservation policy and practice if we aim to protect the highest possible proportion of the species pool.

Until very recently, between-habitat compositional differences have received surprisingly little attention in Eastern European forest-grassland mosaics, where conservation efforts usually focus on only the grassland component (Erdös et al., 2013). In line with the results of Bátori et al. (2018), Kelemen et al. (2017) and Tölgyesi et al. (2017), our study revealed low redundancy between the woody and herbaceous components, which calls for increased efforts to conserve forest habitats in the studied ecosystem.

\subsection{Conservation-related characteristics of the habitats}

One of our most important findings was that the six habitats in the studied ecosystem had strongly different conservation-related characteristics. Grasslands had the highest per plot number of species with special conservation relevance (protected, endemic, red-listed, and specialist species). Similarly, in a mosaic of oak forests and xeric grasslands, Molnár (1998) found that grasslands contained more specialist species than either forest interiors or forest edges. Our results show that the grassland habitat had the highest naturalness. In addition, adventive tree seedlings were completely absent from grasslands, which is in good agreement with earlier studies that indicated low invasibility of undisturbed sand grasslands in the region (Bagi, 2008; Csecserits et al., 2016; Szigetvári, 2002). The conservation importance of the grassland habitat is probably further enhanced by other taxa that were not analysed in this study. For example, sandy grasslands are rich in mosses and lichens, including the endemic species Cladonia magyarica (Borhidi et al., 2012).

In our study, edges (especially north-facing ones) had the highest species richness, which is in line with the edge-effect theory (Risser, 1995). Similarly, forest edges were proven to be quite species-rich in other natural and near-natural mosaics in Eastern Europe (Erdős et al., 2013; Molnár, 1998), Asia (Bátori et al., 2018), and South America (de Casenave et al., 1995; Pinder and Rosso, 1998). In addition to hosting high fine-scale species richness, edges play an important role in tree recruitment: The number of native tree seedlings and saplings was the highest in south-facing edges, but it was also considerable in northfacing ones. Thus, forest edges may play a crucial role in the dynamics of forest-grassland mosaics (Erdős et al., 2015).

Forest patches of different sizes may be substantially dissimilar in several respects, although most earlier studies have been conducted in anthropogenic mosaics (e.g., Carranza et al., 2012; Gignac and Dale, 2007; Kolb and Diekmann, 2005; Rosati et al., 2010). In the finescale natural mosaics of Hungary, forest patches are usually very small (typically up to a few hectares) (Wesche et al., 2016). The small range of forest patch sizes may explain why forest patches of different sizes have received little attention. Interestingly, despite this small variation in size (the lower threshold of the large forest category was only 0.5 ha in our study), considerable differences were found among small forest patches on the one hand, and medium and large forest patches on the other.

Small forest patches had significantly higher species richness, more species of special conservation interest, and higher naturalness than large and medium forest patches. The differences in stand characteristics were less pronounced, although the number of large trees $(\mathrm{DBH}>50 \mathrm{~cm})$ in small forests was low compared to the numbers in medium and large forest patches. Medium and large forest patches had low species richness, only a few species of special conservation relevance, and low naturalness values. In addition, large and medium forest patches hosted the largest proportions of adventive trees; thus, these forests should be 
regarded as potential invasion hot-spots. Csecserits et al. (2016) identified the following habitats as invasion hot-spots in our study region: tree plantations, agricultural habitats, oldfields, and oak forests. Pándi et al. (2014) concluded that abandoned farms are invasion centres. From these sources, adventive species with good dispersal abilities can easily reach all six habitat types evaluated in this study, but they probably have the best establishment chances in relatively humid and cool habitats such as medium and large forest patches.

Medium and large forest patches seemed to have relatively low conservation importance. However, they added structural characteristics to the landscape that small forest patches lacked. The noticeable number of native shrubs and large trees (DBH $>50 \mathrm{~cm}$ ) should be considered important from a conservation perspective. For example, large trees provide habitat for several protected animals, including insects (e.g., Aegosoma scabricorne and Oryctes nasicornis) and birds (e.g., Coracias garrulus and other cavity-nesting birds) (Foit et al., 2016; Gaskó, 2009). It should also be kept in mind that the existence of edges depends on forest patches of sufficient size.

\subsection{Environmental heterogeneity}

Environmental parameters are expected to differ between woody and herbaceous patches in mosaic ecosystems (e.g., Breshears, 2006; Schmidt et al., 2017). In our study, the daily mean temperature differed significantly between woody and herbaceous habitats, while soil moisture showed conspicuous differences among the different woody habitats. Although the causal relations between vegetation and the environment are complex, it may be assumed that trees modify their environment in a way that has a profound effect on the herb layer (cf. Scholes and Archer, 1997). This moderating effect is expected to be especially strong in harsh environments (Callaway and Walker, 1997) such as the semi-arid Kiskunság Sand Ridge.

Soil moisture and daily mean and daytime mean air humidity were higher in the forest patches than in the grasslands, while the daily mean and daytime mean temperature were lower, and the maxima and minima of both temperature and humidity were less extreme in the forest patches. Thus, conserving woody habitats is important for creating environments that are suitable for mesic plants that would be unable to survive in the dry grassland component of the mosaic. This role of trees and groves is predicted to become increasingly important with ongoing climate change (Manning et al., 2009).

\subsection{Conclusions and implications for conservation policy and practice}

Our study implies that maintaining habitat heterogeneity through the protection of various habitats is of crucial conservation importance. Some habitats have outstanding species richness, some possess high resistance against invasion, and others are important mainly for tree recruitment or structural reasons. In addition, all habitats have characteristic species compositions with species that are absent or rare elsewhere.

In concordance with the findings of Török et al. (2017) and Weking et al. (2016), our study suggests that it is not sufficient to focus on either the grassland or the forest components in conservation-oriented research and practice. Rather, an integrated view of the entire mosaic is urgently needed. For example, the establishment of native trees should be promoted in areas where they have been reduced through cutting, overgrazing or fire (e.g., by deploying safe sites for seedlings). Management practices should be adapted to support native tree recruitment (e.g., by decreasing grazing pressure). During restoration projects, the reconstruction of forest patches should be of high priority.

Inappropriate legislation is a possible explanation why the complexity of forestgrassland mosaics has been neglected in both research and management in Eastern Europe (Babai et al., 2015; Hartel et al., 2013; Korotchenko and Peregrym, 2012; Tölgyesi et al., 
2017; Varga et al., 2016). From a legal perspective, an area may be treated as either forest or grassland, but not as a mosaic of both. These two categories (i.e., forest and grassland) do not match reality in Eastern Europe, where the natural vegetation of large areas is actually a mosaic of woody and herbaceous patches.

Adapting conservation policy and practice to fit the complexity of forest-grassland mosaics may be a difficult task; however, there is no alternative if the natural values of these unique ecosystems are to be conserved.

\section{Statement of competing interests}

The authors have no competing interests to declare.

\section{Funding sources and acknowledgements}

Funding: This work was supported by the Hungarian Scientific Research Fund [grant number OTKA PD 116114]; the National Youth Excellence Program [grant number NTPNFTÖ-16-0623]; and the National Research, Development and Innovation Office [grant number NKFIH K 124796]. The funding sources played no role in study design and research conduct. We are thankful to Dolly Tolnay and Mihály Szőke-Tóth for their help with the field work and data analyses.

\section{References}

Armengot, L., Sans, F.X., Fischer, C., Flohre, A., José-María, L., Tscharntke, T., Thies, C., 2012. The $\beta$-diversity of arable weed communities on organic and conventional cereal farms in two contrasting regions. Appl. Veg. Sci. 15, 571-579.

Babai, D., Tóth, A., Szentirmai, I., Biró, M., Máté, A., Demeter, L., Szépligeti, M., Varga, A., Molnár, Á., Kun, R., Molnár, Zs., 2015. Do conservation and agri-environmental regulations effectively support traditional small-scale farming in East-Central European cultural landscapes? Biodivers. Conserv. 24, 3305-3327.

Bagi, I., 2008. Common milkweed (Asclepias syriaca L.), in: Botta-Dukát, Z., Balogh, L. (Eds.), The most important invasive plants in Hungary. MTA ÖBKI, Vácrátót, pp. 151159.

Bates, D., Maechler, M., Bolker, B., Walker, S., 2015. Fitting linear mixed-effects models using lme4. J. Stat. Softw. 67, 1-48.

Bátori, Z., Erdős, L., Kelemen, A., Deák, B., Valkó, O., Gallé, R., Bragina, T.M., Kiss, P.J., Kröel-Dulay, G., Tölgyesi, C., 2018. Diversity patterns in sandy forest-steppes - a comparative study from the western and central Palaearctic. Biodivers. Conserv. 27, 10111030 .

Bazzaz, F.A., 1975. Plant species diversity in old-field successional ecosystems in southern Illinois. Ecology 56, 485-488.

Bennett, A.F., Radford, J.T., Haslem, A., 2006. Properties of land mosaics: Implications for nature conservation in agricultural environments. Biol. Conserv. 133, 250-264.

Benton, T.G., Vickery, J.A., Wilson, J.D., 2003. Farmland biodiversity: Is habitat heterogeneity the key? Trends Ecol. Evol. 18, 182-188.

Bergmeier, E., Petermann, J., Schröder, E., 2010. Geobotanical survey of wood-pasture habitats in Europe: diversity, threats and conservation. Biodivers. Conserv. 11, 2995-3014.

Biró, M., Szitár, K., Horváth, F., Bagi, I., Molnár, Zs., 2013. Detection of long-term landscape changes and trajectories in a Pannonian sand region: comparing land-cover and habitat-based approaches at two spatial scales. Community Ecol. 14, 219-230.

Bodrogközy, Gy., 1982. Hydroecology of the vegetation of sandy forest-steppe character in the Emlékerdő at Ásotthalom. Acta Biol. Szeged. 28, 13-39. 
Borhidi, A., 1995. Social behaviour types, the naturalness and relative ecological indicator values of the higher plants in the Hungarian Flora. Acta Bot. Hung. 39, 97-181.

Borhidi, A., Kevey, B., Lendvai, G., 2012. Plant communities of Hungary. Academic Press, Budapest.

Breshears, D.D., 2006. The grassland-forest continuum: Trends in ecosystem properties for woody plant mosaics? Front. Ecol. Environ. 4, 96-104.

Callaway, R.M., Walker, L.R., 1997. Competition and facilitation: a synthetic approach to interactions in plant communities. Ecology 78, 1958-1965.

Carranza M.L., Frate, L., Paura, B., 2012. Structure, ecology and plant richness patterns in fragmented beech forests. Plant Ecol. Divers. 5, 541-551.

Chesson, P., 2000. Mechanisms of maintenance of species diversity. Annu. Rev. Ecol. Syst. 31, 343-366. Chytrý, M., Tichý, L., Holt, J., Botta-Dukát, Z., 2002. Determination of diagnostic species with statistical fidelity measures. J. Veg. Sci. 13, 79-90.

Csecserits, A., Botta-Dukát, Z., Kröel-Dulay, Gy., Lhotsky, B., Ónodi, G., Rédei, T., Szitár, K., Halassy, M., 2016. Tree plantations are hot-spots of plant invasion in a landscape with heterogeneous land-use. Agr. Ecosyst. Environ. 226, 88-98.

de Casenave, J.L., Pelotto, J.P., Protomastro, J., 1995. Edge-interior differences in vegetation structure and composition in a Chaco semi-arid forest, Argentina. Forest Ecol. Manag. 72, $1-169$.

Diekmann, M., 2003. Species indicator values as an important tool in applied plant ecology: a review. Basic Appl. Ecol. 4, 493-506.

Dorresteijn, I., Teixeira, L., Von Wehrden, H., Loos, J., Hanspach, J., Stein, J.A.R., Fischer, J., 2015. Impact of land cover homogenization on the Corncrake (Crex crex) in traditional farmland. Landscape Ecol. 30, 1483-1495.Erdős, L., Ambarl1, D., Anenkhonov, O.A., Bátori, Z., Cserhalmi, D., Kiss, M., Kröel-Dulay, Gy., Liu, H., Magnes, M., Molnár, Zs., Naqinezhad, A., Semenishchenkov, Y.A., Tölgyesi, Cs., Török, P., 2018. The edge of two worlds: A new review and synthesis on Eurasian forest-steppes. Appl. Veg. Sci. doi: 10.1111 /avsc. 12382

Erdős, L., Bátori, Z., Penksza, K., Dénes, A., Kevey, B., Kevey, D., Magnes, M., Sengl, P., Tölgyesi, C., 2017. Can naturalness indicator values reveal habitat degradation? A test of four methodological approaches. Pol. J. Ecol. 65, 1-13.

Erdős, L., Gallé, R., Körmöczi, L., Bátori, Z., 2013. Species composition and diversity of natural forest edges: Edge responses and local edge species. Community Ecol. 14, 48-58. Erdős, L., Tölgyesi, C., Cseh, V., Tolnay, D., Cserhalmi, D., Körmöczi, L., Gellény, K., Bátori, Z., 2015. Vegetation history, recent dynamics and future prospects of a Hungarian sandy forest-steppe reserve: Forest-grassland relations, tree species composition and sizeclass distribution. Community Ecol. 16, 95-105.

Ernst, L.M., Tscharntke, T., Batáry, P., 2017. Grassland management in agricultural vs. forested landscapes drives butterfly and bird diversity. Biol. Conserv. 216, 51-59.

Fekete, G., 1992. The holistic view of succession reconsidered. Coenoses 7, 21-29.

Filatova, T., Zolotukhin, N., 2002. Artificial steppe restoration in Russia and Ukraine. Ecol. Restor. 20, 241-242.Foit, J., Kašák, J., Nevoral, J., 2016. Habitat requirements of the endangered longhorn beetle Aegosoma scabricorne (Coleoptera: Cerambycidae): A possible umbrella species for saproxylic beetles in European lowland forests. J. Insect Conserv. 20, 837-844.

Foley, J.A., DeFries, R., Asner, G.P., Barford, C., Bonan, G., Carpenter, S.R., Chapin, F.S., Coe M.T., Daily, G.C., Gibbs, H.K., Helkowski, J.H., Holloway, T., Howard, E.A., Kucharik, C.J., Monfreda, C., Patz, J.A., Prentice, I.C., Ramankutty, N., Snyder, P.K., 2005. Global consequences of land use. Science 309, 570-574. 
Gaskó, B., 2009. Csongrád megye természetes és természetközeli élőhelyeinek védelméről II. [On the protection of natural and near-natural habitats in Csongrád county II.] Studia Naturalia 5, 5-486.

Gignac, L.D., Dale, M.R.T., 2007. Effects of size, shape, and edge on vegetation in remnants of the upland boreal mixed-wood forest in agro-environments of Alberta, Canada. Can. J. Botany 85, 273-284.

Halassy, M., Singh, N.A., Szabó, R., Szili-Kovács, T., Szitár, K., Török, K., 2016. The application of a filter-based assembly model to develop best practices for Pannonian sand grassland restoration. J. Appl. Ecol. 53, 765-773.

Hartel, T., Dorresteijn, I., Klein, C., Máthé, O., Moga, C.I., Öllerer, K., Roellig, M., von Wehrden, H., Fischer, J., 2013. Wood-pastures in a traditional rural region of Eastern Europe: Characteristics, management and status. Biol. Conserv. 166, 267-275.

Jakobsson, S., Lindborg, R., 2015. Governing nature by numbers - EU subsidy regulations do not capture the unique values of woody pastures. Biological Conservation 191, 1-9.

Kelemen, A, Tölgyesi, C., Kun, R., Molnár, Z., Vadász, C., Tóth, K., 2017. Positive smallscale effects of shrubs on diversity and flowering in pastures. Tuexenia 37, 399413.Kertész, M., Aszalós, R., Lengyel, A., Ónodi, G., 2017. Synergistic effects of the components of global change: Increased vegetation dynamics in open, forest-steppe grasslands driven by wildfires and year-to-year precipitation differences. PloS One 12, e0188260.Király, G., (Ed.) 2007. Red list of the vascular flora of Hungary. Private Edition, Sopron.

Király, G., (Ed.) 2009. Új magyar füvészkönyv [New key to the vascular flora of Hungary]. Aggtelek National Park, Jósvafö.

Kolb, A., Diekmann, M., 2005. Effects of life-history traits on responses of plant species to forest fragmentation. Conserv. Biol. 19, 929-938.

Korotchenko, I., Peregrym, M., 2012. Ukrainian steppes in the past, at present and in the future, in: Werger, M.J.A., van Staalduinen, M.A. (Eds.), Eurasian steppes. Ecological problems and livelihoods in a changing world. Springer, Dordrecht, pp. 173-196.

Luza, A.L., Carlucci, M.B., Hartz, S.M., Duarte, L.D.S., 2014. Moving from forest vs. grassland perspectives to an integrated view towards the conservation of forest-grassland mosaics. Nat. Conservacao 12, 166-169.

Lee, M-B., Martin, J.A., 2017. Avian species and functional diversity in agricultural landscapes: Does landscape heterogeneity matter? PLoS One 12, e0170540.Manning, A.D., Fischer, J., Lindenmayer, D., 2006. Scattered trees as keystone structures implications for conservation. Biol. Conserv. 132, 311-321.Manning, A.D., Gibbons, P., Lindenmayer, D.B., 2009. Scattered trees: a complementary strategy for facilitating adaptive responses to climate change in modified landscapes? J. Appl. Ecol., 46, 915-919.

Molnár, Zs., 1998. Interpreting present vegetation features by landscape historical data: an example from a woodland-grassland mosaic landscape (Nagykőrös Wood, Kiskunság Hungary), in: Kirby, K.J., Watkins, C. (Eds.), The ecological history of European forests. CAB International, Wallingford, pp. 241-263.

Moreno, G., Aviron, S., Berg, S., Crous-Duran, J., Franca, A., García de Jalón, S., Hartel, T., Mirck, J., Pantera, A., Palma, J.H.N., Paulo, J.A., Re, G.A., Sanna, F., Thenail, C., Varga, A., Viaud, V., Burgess, P.J., 2017. Agroforestry systems of high nature and cultural value in Europe: provision of commercial goods and other ecosystem services. Agroforest. Syst. doi: 10.1007/s10457-017-0126-1

Oksanen, J., Blanchet, F.G., Friendly, M., Kindt, R., Legendre, P., McGlinn, D., Peter R. Minchin, P.R., O'Hara, R.B., Simpson, G.L., Solymos, P., Henry, M., Stevens, H., Szoecs, 
E., Wagner, H., 2016. vegan: Community Ecology Package. R package version 2.4-1. https://CRAN.R-project.org/package=vegan (last accessed 12 September 2017).

Öllerer, K., 2014. The ground vegetation management of wood-pastures in Romania-Insights in the past for conservation management in the future. Appl. Ecol. Env. Res. 12, 549-562.

Pándi, I., Penksza, K., Botta-Dukát, Z., Kröel-Dulay, Gy., 2014. People move but cultivated plants stay: abandoned farmsteads support the persistence and spread of alien plants. Biodivers. Conserv. 23, 1289-1302.

Pinder, L., Rosso, S., 1998. Classification and ordination of plant formations in the Pantanal of Brazil. Plant Ecol. 136, 152-165.

Pinheiro, J., Bates, D., DebRoy, S., Sarkar, D., R Core Team, 2016. nlme: Linear and Nonlinear Mixed Effects Models. R package version 3.1-128. http://CRAN.Rproject.org/package $=$ nlme (last accessed 12 September 2017).

Plieninger ,T., Hartel, T., Marin-Lopez, B., Beaufoy, G., Kirby, K., Montero, M.J., Moreno, G., Oteros-Rozas, E., Van Uytvanck, J., 2015. Wood-pastures of Europe: geographic coverage, social-ecological values, conservation management, and policy. Biol. Conserv. 190, 70-79.

Prevedello, J.A., Almeida-Gomes, M., Lindenmayer, D.B., 2018. The importance of scattered trees for biodiversity conservation: A global meta-analysis. J. Appl. Ecol. 55, 205-214.R Core Team, 2017. R: A language and environment for statistical computing. https://www.R-project.org/ (last accessed 12 September 2017).

Rembold, K., Mangopo, H., Tjitrosoedirdjo, S.S., Kreft, H., 2017. Plant diversity, forest dependency, and alien plant invasions in tropical agricultural landscapes. Biol. Conserv. 213, 234-242.

Risser, P.G., 1995. The status of the science examining ecotones. BioScience 45, 318-325.

Rosati, L., Fipaldini, M., Marignani, M., Blasi, C., 2010. Effects of fragmentation on vascular plant diversity in a Mediterranean forest archipelago. Plant Biosyst. 144, 38-46.Schmidt, M., Jochheim, H., Kersebaum, K.C., Lischeid, G., Nendel, C., 2017. Gradients of microclimate, carbon and nitrogen in transition zones of fragmented landscapes - a review. Agr. Forest Meteorol. 232, 659-671.

Scholes, R.J., Archer, S.R., 1997. Tree-grass interactions in savannas. Annu. Rev. Ecol. Syst. 28, 517-544.Schultz, J., 2005. The ecozones of the world. Springer, Berlin.

Sengl, P., Magnes, M., Erdős, L., Berg, C., 2017. A test of naturalness indicator values to evaluate success in grassland restoration. Community Ecol. 18, 184-192.Sengl, P., Magnes, M., Wagner, V., Erdős, L., Berg, C., 2016. Only large and highly-connected semidry grasslands achieve plant conservation targets in an agricultural matrix. Tuexenia 36, 167-190.Stoate, C., Boatman, N.D., Borralho, R.J., Carvalho, C.R., de Snoo, G.R., Eden, P., 2001. Ecological impacts of arable intensification in Europe. J. Environ. Manage. 63, 337-365.

Szigetvári, C., 2002. Distribution and phytosociological relations of two introduced plant species in an open sand grassland area in the Great Hungarian Plain. Acta Bot. Hung. 44, 163-183.Szitár, K., Ónodi, G., Somay, L., Pándi, I., Kucs, P., Kröel-Dulay, G., 2016. Contrasting effects of land use legacies on grassland restoration in burnt pine plantations. Biol. Conserv. 201, 356-362.Tews, J., Brose, U., Grimm, V., Tielbörger, K., Wichmann, M.C., Schwager, M., Jeltsch, F., 2004. Animal species diversity driven by habitat heterogeneity/diversity: the importance of keystone structures. J. Biogeogr. 31, 7992.Tichý, L., 2002. JUICE, software for vegetation classification. J. Veg. Sci. 13, 451453.Tilman, D., 1982. Resource competition and community structure. Princeton University Press, Princeton. 
Tölgyesi, C., Bátori, Z., Erdős, L., 2014. Using statistical tests on relative ecological indicators to compare vegetation units - different approaches and weighting methods. Ecol. Indic. 36, 441-446.

Tölgyesi, C., Bátori, Z., Gallé, R., Urák, I., Hartel, T., 2017. Shrub encroachment under the trees diversifies the herb layer in a Romanian silvopastoral System. Rangeland Ecol. Manag. doi: 10.1016/j.rama.2017.09.004

Tölgyesi, C., Zalatnai, M., Erdős, L., Bátori, Z., Hupp, N.R., Körmöczi, L., 2016. Unexpected ecotone dynamics of a sand dune vegetation complex following water table decline. J. Plant Ecol. 9, 40-50.

Török, K., Szitár, K., Halassy, M., Szabó, R., Szili-Kovács, T., Baráth, N., Paschke, M.W., 2014. Long-term outcome of nitrogen immobilization to restore endemic sand grassland in Hungary. J. Appl. Ecol. 51, 756-765.

Török, K., Csecserits, A., Somodi, I., Kövendi-Jakó, A., Halász, K., Rédei, T., Halassy, M., 2017. Restoration prioritization for industrial area applying multiple potential natural vegetation modeling. Restor. Ecol. doi: 10.1111/rec.12584

Tscharntke, T., Klein, A.M., Kruess, A., Steffan-Dewenter, I., Thies, C., 2005. Landscape perspectives on agricultural intensification and biodiversity - ecosystem service management. Ecol. Lett. 8, 857-874.

Valkó, O., Török, P., Matus, G., Tóthmérész, B., 2012. Is regular mowing the most appropriate and cost-effective management maintaining diversity and biomass of target forbs in mountain hay meadows? Flora 207, 303-309.

Várallyay, G., 1993. Soils in the region between the Rivers Danube and Tisza (Hungary), in: Szujkó-Lacza, J., Kováts, D. (Eds.), The flora of the Kiskunság National Park. Hungarian Natural History Museum, Budapest, pp. 21-42.

Varga, A., Molnár, Zs., Biró, M., Demeter, L., Gellény, K., Miókovics, E., Molnár, Á., Molnár, K., Ujházy, N., Ulicsni, V., Babai, D., 2016. Changing year-round habitat use of extensively grazing cattle, sheep and pigs in East-Central Europe between 1940 and 2014: Consequences for conservation and policy. Agr. Ecosyst. Environ. 234, 142-153.

Weking, S., Kämpf, I., Mathar, W., Hölzel, N., 2016. Effects of land use and landscape patterns on Orthoptera communities in the Western Siberian forest steppe. Biodivers. Conserv. 25, 2341-2359.Wesche, K., Ambarl,, D., Kamp, J., Török, P., Treiber, J., Dengler, J., 2016. The Palaearctic steppe biome: A new synthesis. Biodivers. Conserv. 25, 2197-2231. 
A
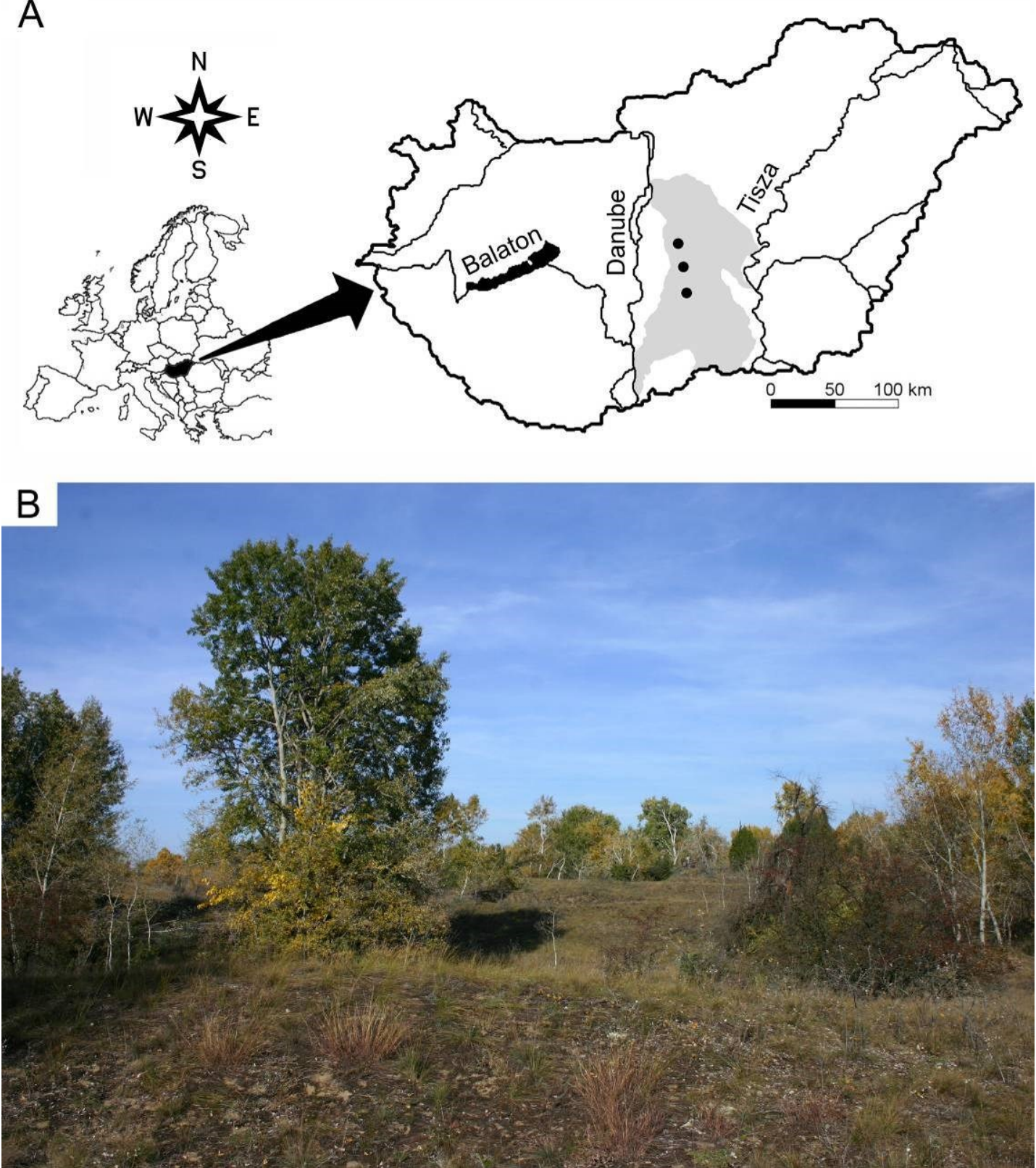

623

Fig. 1. (a) Locations of the Kiskunság Sand Ridge (grey) between the Danube and Tisza rivers in Hungary and the three study sites (black dots); from north to south: Tatárszentgyörgy, Fülöpháza, Bócsa. (b) Mosaic of woody and herbaceous vegetation at the Fülöpháza site. 
(grayscale figure to be published in print)

630

A

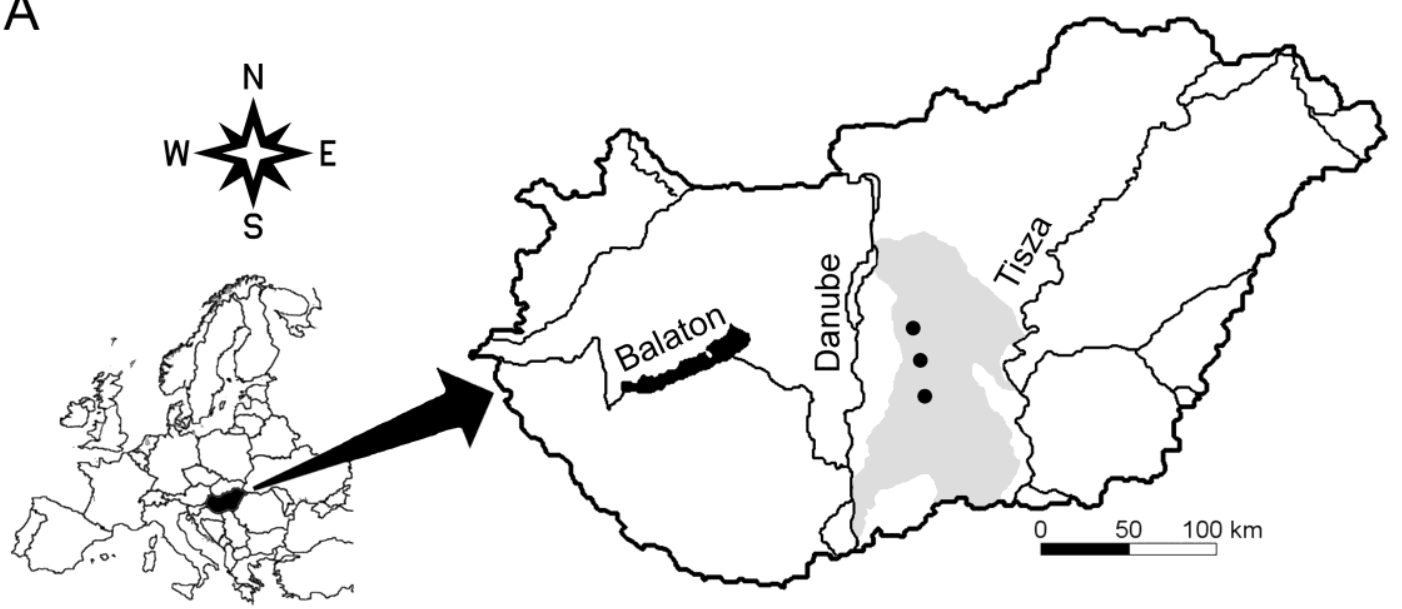

B

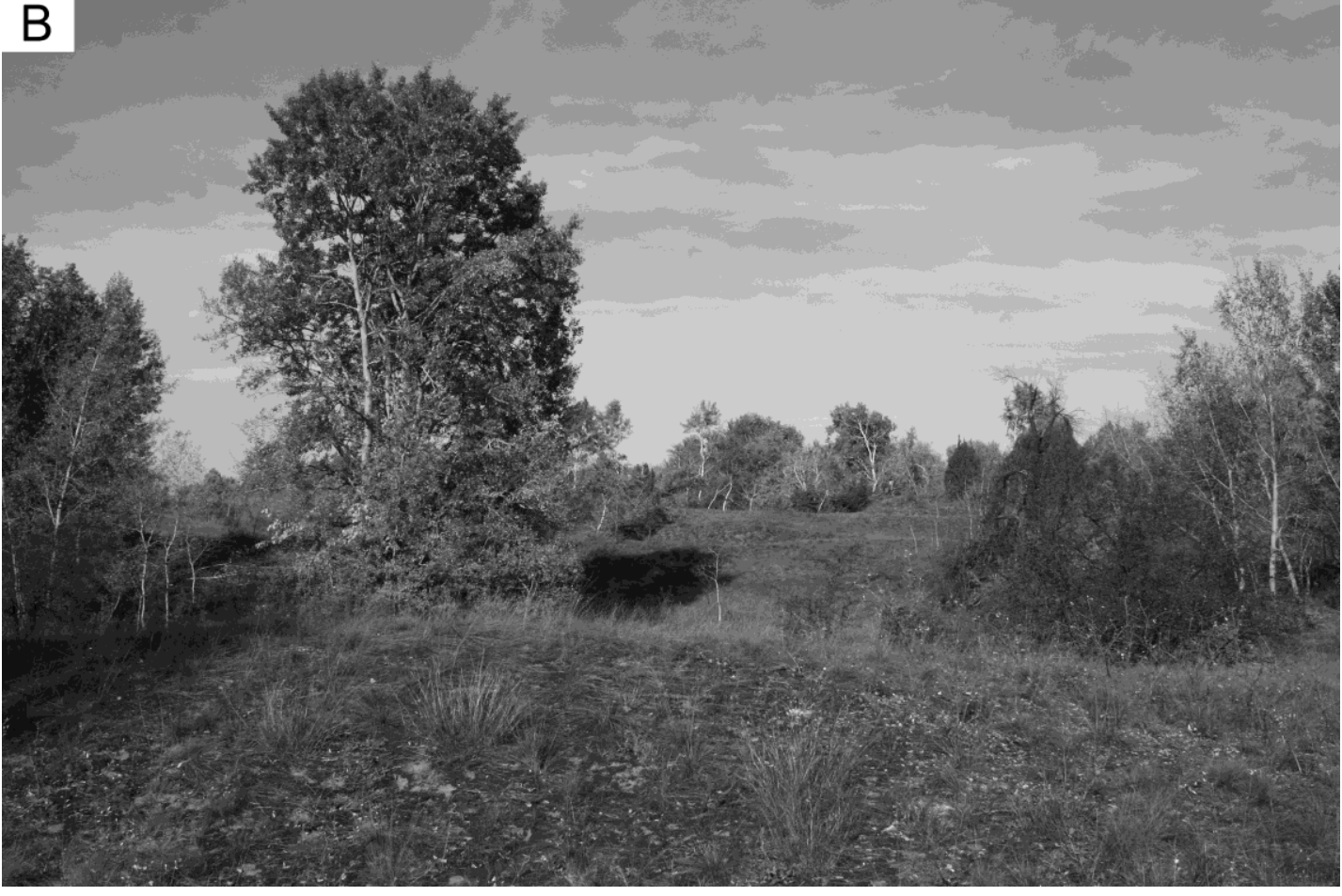




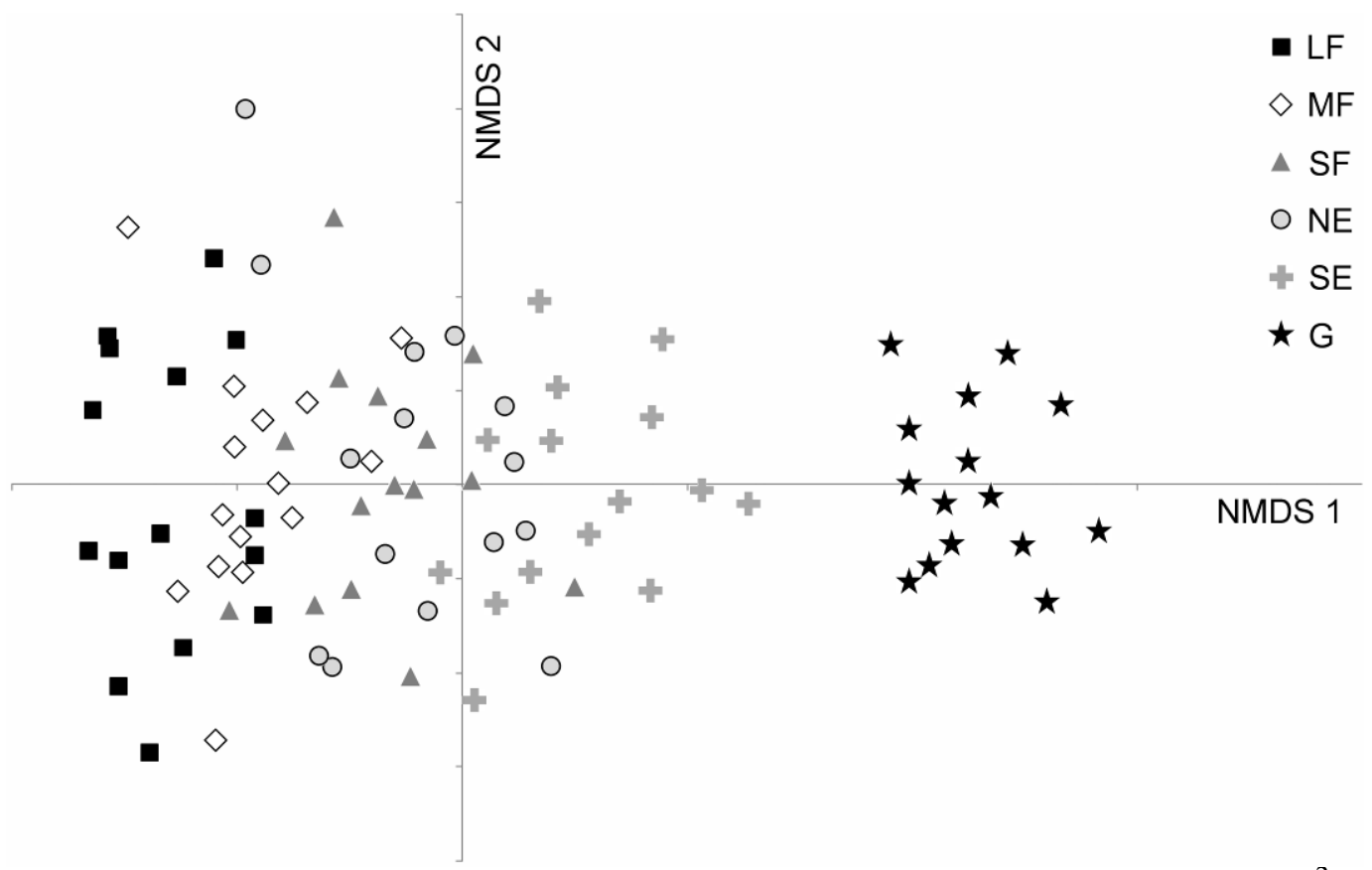

Fig. 2. NMDS ordination scattergram of the 90 relevés. Stress factor: $0.149 ; \mathrm{R}^{2}{ }_{\mathrm{NMDS} 2}=0.820$, $\mathrm{R}_{\text {NMDS1 }}^{2}=0.035$. LF: large forest patches, MF: medium forest patches, $\mathrm{SF}$ : small forest patches, NE: north-facing edges, SE: south-facing edges, G: grasslands. 

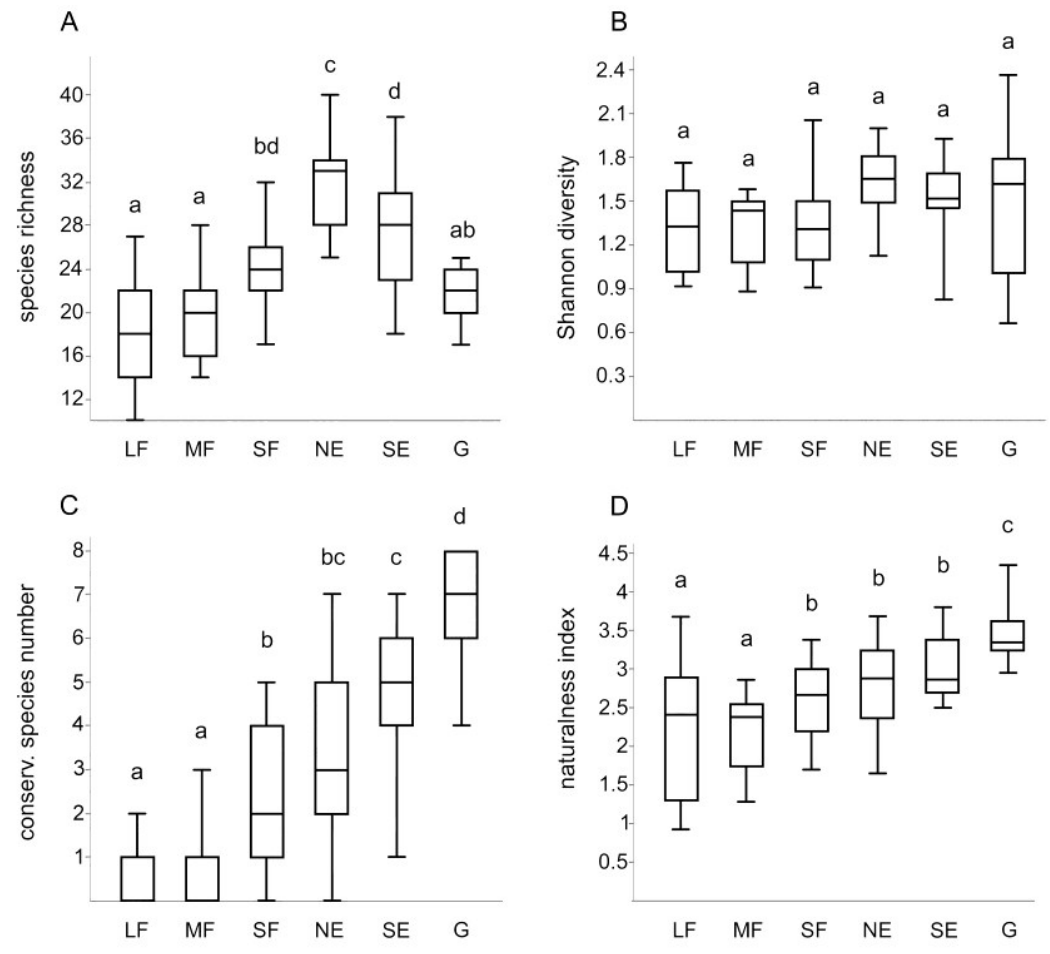

Fig. 3. Species richness (A), Shannon diversity (B), the number of species with special conservation importance (C), and mean naturalness values (D) of the six habitats. Different letters above the boxes indicate significant differences. LF: large forest patches, MF: medium forest patches, SF: small forest patches, NE: north-facing edges, SE: south-facing edges, G: grasslands. 
A

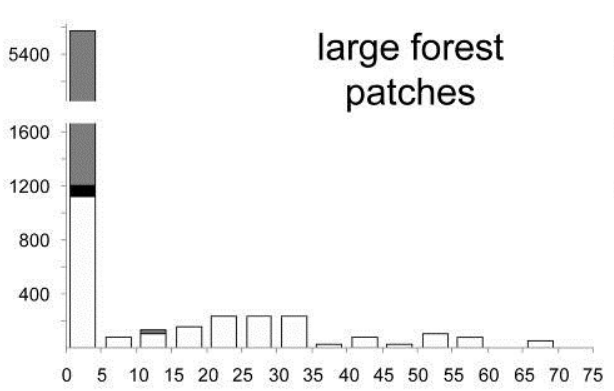

C
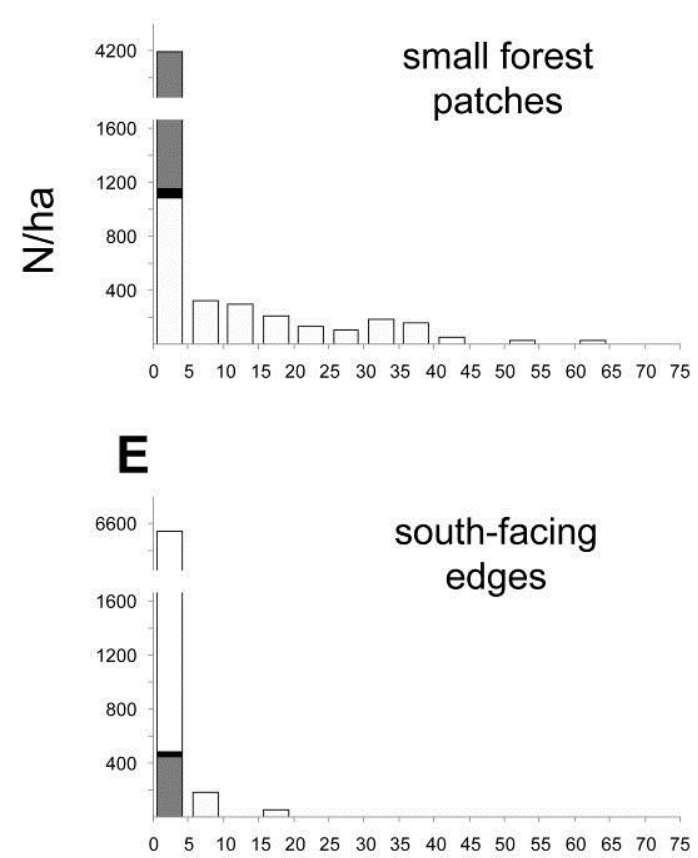

B

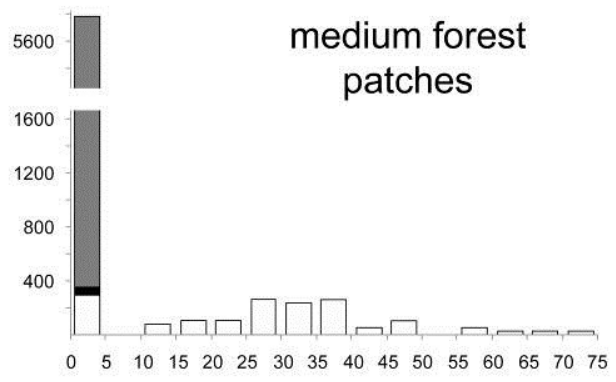

D

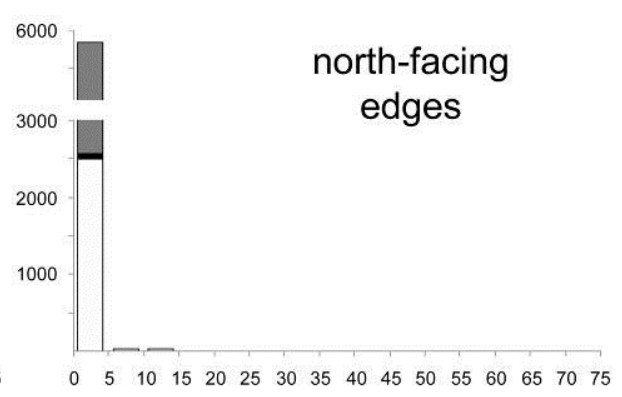

F

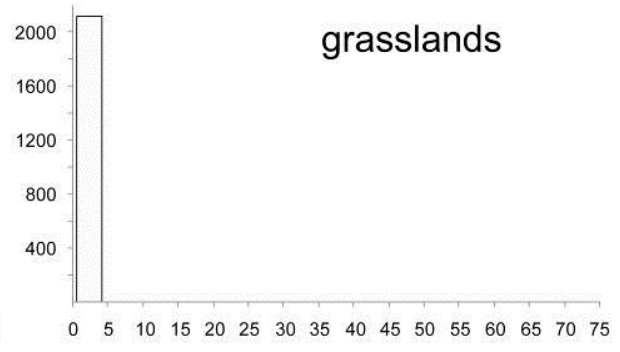

\section{$\mathrm{DBH}(\mathrm{cm})$}

645

Fig. 4. DBH class distribution of Populus alba + P. $\times$ canescens (white), other native trees (black), and adventve trees (grey) in large forest patches (A), medium forest patches (B), small forest patches (C), north-facing edges (D), south-facing edges (E), and grasslands (F). 


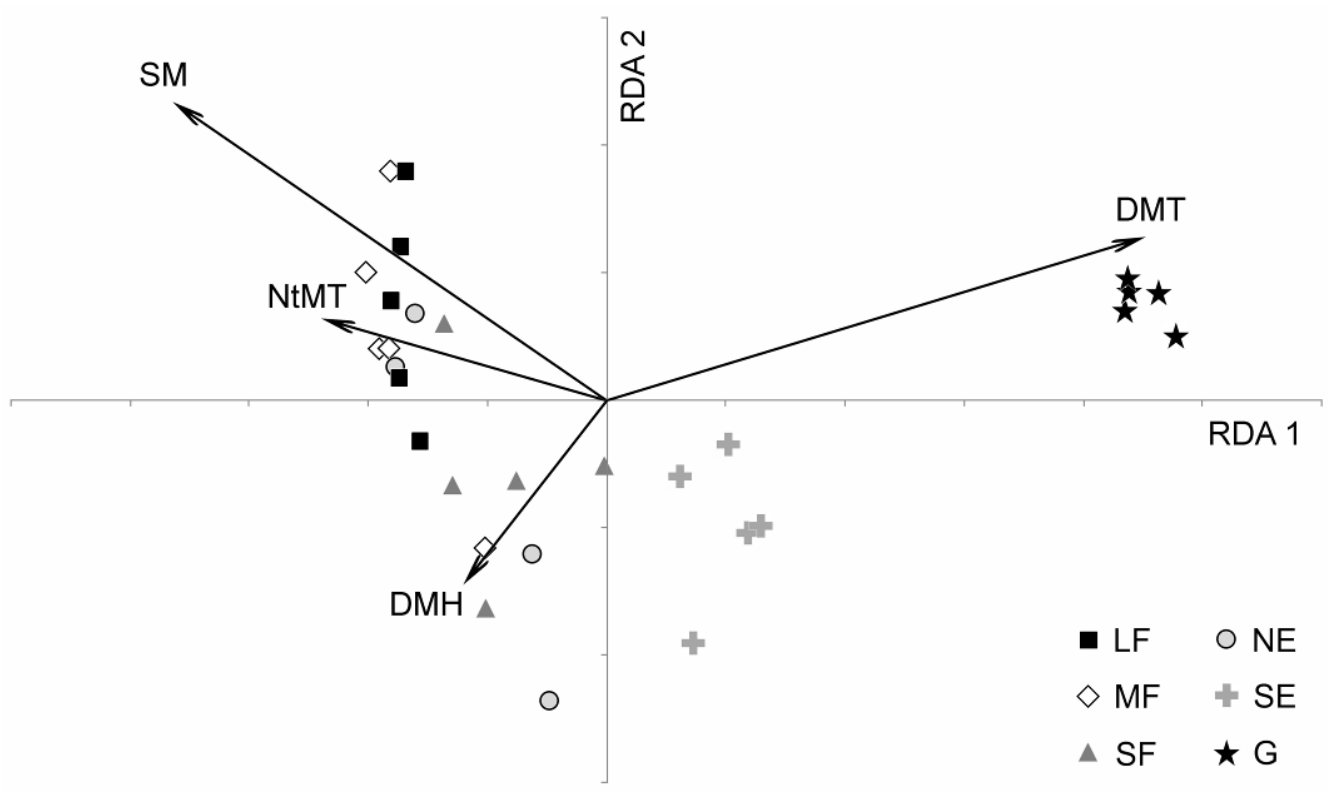

Fig. 5. Biplot of the dbRDA of the six main habitats in Fülöpháza. Constrained inertia: 37.6, unconstrained inertia: 62.4\%; eigenvalues of the first and second axes: 2.170 and 0.256 , respectively. DMT: daily mean temperature, DMH: daily mean relative humidity, NtMT: nighttime mean temperature, SM: soil moisture; LF: large forest patches, MF: medium forest patches, SF: small forest patches, NE: north-facing edges, SE: south-facing edges, G: grasslands. 
661

\begin{tabular}{|c|c|c|c|c|c|c|}
\hline & LF & MF & SF & $\mathrm{NE}$ & SE & $G$ \\
\hline \multicolumn{7}{|l|}{$\mathrm{DBH}<5 \mathrm{~cm}$} \\
\hline $\mathrm{N} /$ ha native trees & 1200.0 & 346.7 & 1146.7 & 2560.0 & 6080.0 & 2106.7 \\
\hline $\mathrm{N} / \mathrm{ha}$ adventive trees & 4373.3 & 5440.0 & 3040.0 & 3280.0 & 453.3 & - \\
\hline \multicolumn{7}{|l|}{$\mathrm{DBH}>5 \mathrm{~cm}$} \\
\hline $\mathrm{N} /$ ha native trees & 1440.0 & 1360.0 & 1520.0 & 53.3 & 240.0 & - \\
\hline $\mathrm{N} / \mathrm{ha}$ adventive trees & 26.7 & - & - & - & - & - \\
\hline mean DBH $(\mathrm{cm})$ & 30.3 & 33.9 & 22.0 & 8.3 & 7.9 & - \\
\hline \multicolumn{7}{|l|}{$\mathrm{DBH}>50 \mathrm{~cm}$} \\
\hline $\mathrm{N} /$ ha native trees & 240.0 & 133.3 & 53.3 & - & - & - \\
\hline $\mathrm{N} / \mathrm{ha}$ adventive trees & - & - & - & - & - & - \\
\hline $\max . \mathrm{DBH}(\mathrm{cm})$ & 68.4 & 70.0 & 62.7 & 10.5 & 16.9 & - \\
\hline
\end{tabular}

Table 1. Stand characteristics of the six habitats. LF: large forest patches, MF: medium forest patches, SF: small forest patches, NE: north-facing edges, SE: south-facing edges, G: grasslands. 
664 Table 2. Results of the Kolmogorov-Smirnov tests for the six habitats regarding DBH class 665 distribution. LF: large forest patches, MF: medium forest patches, SF: small forest patches, 666 NE: north-facing edges, SE: south-facing edges, G: grasslands.

667

\begin{tabular}{llllllc}
\hline \multicolumn{1}{c}{ DIP } & LF & MF & SF & NE & SE & G \\
LF & & 0.994 & 0.968 & $<\mathbf{0 . 0 0 1}$ & $\mathbf{0 . 0 0 1}$ & $<\mathbf{0 . 0 0 1}$ \\
MF & 0.13 & & 0.849 & $<\mathbf{0 . 0 0 1}$ & $\mathbf{0 . 0 0 2}$ & $<\mathbf{0 . 0 0 1}$ \\
SF & 0.13 & 0.20 & & $\mathbf{0 . 0 1 0}$ & $\mathbf{0 . 0 1 3}$ & $<\mathbf{0 . 0 0 1}$ \\
NE & 0.67 & 0.67 & 0.53 & & 0.863 & 0.735 \\
SE & 0.67 & 0.67 & 0.53 & 0.13 & & 0.724 \\
G & 0.80 & 0.80 & 0.67 & 0.13 & 0.13 & \\
\hline
\end{tabular}

